\title{
Development and quality evaluation of antioxidant rich star fruit beverages (Averrhoa carambola)
}

\author{
Anamika Gautam and Shashi Jain
}

Consumption of various types of fruit provides excellent health benefits because they are good source of phytochemicals and prevent many diseases. The protective action of fruits and vegetables has been attributed to the presence of antioxidants. In this view of above, the present study had been planned with the objectives to develop and assess the nutritional, antioxidant and shelf-life properties of antioxidant rich healthy beverages formulated using star fruit. Moisture, crude protein, crude fat, total ash and carbohydrate content present in Squash was $48.71 \pm 0.19 \mathrm{~g}, 0.2 \pm 0.01 \mathrm{~g}, 0.17 \pm 0.005 \mathrm{~g}$, $50.87 \pm 0.20 \mathrm{~g}$ per $100 \mathrm{~g}$, respectively. Crude fibre was not present in Squash. The energy value was $204.63 \pm 0.77 \mathrm{kcal}$ per 100 g. Developed Squash had contained $19.17 \pm 0.21 \mathrm{mg}$ calcium, $0.05 \pm 0.01 \mathrm{mg}$ potassium and $1.27 \pm 0.04 \mathrm{mg}$ magnesium per 100 $\mathrm{g}$. In this sequence, proximate composition of Cordial was; moisture $54.03 \pm 0.02 \mathrm{~g}$, total ash $0.15 \pm 0.01 \mathrm{~g}$, carbohydrate $45.82 \pm 0.01 \mathrm{~g}$ and energy $183.28 \pm 0.06 \mathrm{kcal}$ per $100 \mathrm{~g}$. Crude protein, crude fat and crude fibre was detected in Cordial. Mineral content in Cordial which includes calcium, potassium and magnesium was $0.05 \pm 0.005 \mathrm{mg}, 0.05 \pm 0.01 \mathrm{mg}$ and $0.02 \pm 0.005 \mathrm{mg}$ per $100 \mathrm{~g}$, respectively. The total antioxidant activity, total phenolic content and ascorbic acid present in Squash was $70.91 \pm 0.38 \%, 261.71 \pm 0.49$ and $2.09 \pm 0.19 \mathrm{mg}$ per 100 , g respectively. Total antioxidant capacity in Cordial was $67.82 \pm 0.26 \%$. The total phenolic content and ascorbic acid value of Cordial was $244.03 \pm 0.49$ and $1.46 \pm 0.14 \mathrm{mg}$ per $100 \mathrm{~g}$, respectively. The organoleptic scores for Squash and Cordial during storage were slightly decreases during the storage period $\left(0^{\text {th }}\right.$ to $90^{\text {th }}$ days $)$ but the scores were between "liked moderately" to "liked very much". The effect of storage on total antioxidant capacity of Squash and Cordial revealed that during the storage period the total antioxidant activity was decreases, but it was in the range from $70.91 \pm 0.38 \%$ to $64.65 \pm 0.11 \%$ for Squash and $67.82 \pm 0.26 \%$ to $60.26 \pm 0.15 \%$ for Cordial. So, it was concluded that developed Squash and Cordial were found highly acceptable when they were developed using Star Fruits.

Key Words : Star fruit, Phy- tochemicals,Antioxidant, Phenolic compound, Vitamin C, Shelf-life, Organoleptic evaluation

How to cite this article : Gautam, Anamika and Jain, Shashi (2018). Development and quality evaluation of antioxidant rich star fruit beverages (Averrhoa carambola). Food Sci. Res. J., 9(2): 426-430, DOI : 10.15740/HAS/FSRJ/9.2/426-430.Copyright@ 2018: Hind Agri-Horticultural Society. 